\title{
Correction to: Nutrient enrichment and altered temperature regime explain litter decomposition in cold-temperate urban streams
}

\author{
Marina Tagliaferro $($ Deonardo Buria $\cdot$ \\ Adonis Giorgi $\cdot$ Ricardo Albariño
}

Published online: 8 February 2022

(C) The Author(s), under exclusive licence to Springer Nature Switzerland AG 2022

\section{Correction to: Hydrobiologia https://doi.org/10.1007/s10750- 022-04796-x}

In the above mentioned publication, the affiliation of L. Buria was interchanged with the second affiliation of A. Giorgi. The correct affiliations are displayed here and the original article has been corrected.

The original article can be found online at https://doi.org/ 10.1007/s10750-022-04796-X.

M. Tagliaferro $(\bowtie)$

Centro Austral de Investigaciones Científicas (CADICCONICET), B. Houssay 200, Ushuaia, Tierra del Fuego, Argentina

e-mail: azulmarinita@gmail.com;

marina.tagliaferro@conicet.gob.ar

M. Tagliaferro · A. Giorgi

Instituto de Ecología y Desarrollo Sustentable (INEDESCONICET) - Universidad Nacional de Luján, Ruta 5 y Av.

Constitución, 6700 Luján, Buenos Aires, Argentina

L. Buria

Delegación Regional Patagonia, Administración de

Parques Nacionales, San Carlos de Bariloche, Argentina
Publisher's Note Springer Nature remains neutral with regard to jurisdictional claims in published maps and institutional affiliations.

\author{
A. Giorgi \\ Departamento de Ciencias Básicas - Universidad Nacional \\ de Luján, Ruta 5 y Av. Constitución, 6700 Luján, \\ Buenos Aires, Argentina \\ R. Albariño \\ Instituto de Investigaciones en Biodiversidad y \\ Medioambiente (INIBIOMA,-- Universidad Nacional del \\ Comahue - CONICET), Quintral 1250, 8400 Bariloche, \\ Argentina
}

